\title{
Designing of ultraviolet irradiation unit: Effects on disinfection performance and operating costs
}

\section{Ultraviyole ışınlama ünitesinin dizaynı: Dezenfeksiyon performansı ve işletme maliyetleri üzerine etkileri}

\author{
Halil Şen* (10) • Ulviye Karacalar \\ Ege University Faculty of Fisheries, Department of Aquaculture, 35440, Urla, İzmir, Turkey \\ * Corresponding author: halil.sen@ege.edu.tr
}

How to cite this paper:

Şen, H. \& Karacalar, U. (2018). Designing of ultraviolet irradiation unit: Effects on disinfection performance and operating costs. Ege Journal of Fisheries and Aquatic Sciences, 35(2), 121-124. DOI:10.12714/egejfas.2018.35.2.03

Abstract: The effect of the design of ultraviolet irradiation unit on disinfection performance and operating costs was investigated for aquaculture purposes. Two prototypes ( $\mathrm{H}$ and $\mathrm{U}$ ) were compared with a commercial UV filter (I). The water samples for microbiological cultivation were obtained from water inlet and outlet of three different types of UV units in four replicates at $15^{\circ} \mathrm{C}$ and $25^{\circ} \mathrm{C}$ of sea water temperatures. Finally, considering the efficiency of reduction the total heterotrophic bacterial load of the UV filters, although significant differences were not found statistically, the best results were obtained from U type UV chamber at both temperatures $\left(15^{\circ} \mathrm{C}\right.$ and $\left.25^{\circ} \mathrm{C}\right)(P>0.05)$. Also, it was estimated that make $60 \%$ savings in renewal and operating costs can be possible with changing the design of UV chamber.

Keywords: aquaculture, design, disinfection, filter, ultraviolet

Öz: Akuakültür kullanımları için ultraviyole ışılama ünite tasarımının dezenfeksiyon verimine ve işletme maliyetlerine etkisi incelenmiştir. İki prototip (H ve U), ticari bir UV filtresiyle (I) karşılaştırımıştır. Mikrobiyal ekim için su örnekleri $15^{\circ} \mathrm{C}$ ve $25^{\circ} \mathrm{C}$ su sıcaklığında dört tekrarlı olarak her üç ultraviyole filtrenin su girişi ve çıkışından alınmıştır. Son olarak, UV filtreler arasında istatistiksel olarak önemli farklılık bulunmamakla birlikte, en iyi filtreleme performansı, $15^{\circ} \mathrm{C}$ ve $25^{\circ} \mathrm{C}$ su sıcaklıklarında, U tipi UV filtreden sağlanmıştır $(P>0,05)$. Ayrıca, sadece UV ünitesinin tasarımını değiştirerek bakım - onarım ve işletme maliyetlerinde \%60 tasarruf yapılabileceği hesaplanmıştır.

Anahtar kelimeler: Akuakültür, tasarım, dezenfeksiyon, filter, ultraviyole

\section{INTRODUCTION}

In aquaculture industry, antibiotics may be effective in treating pathogens, but antibiotic resistance is common and most antibiotics are not registered for use in aquaculture (Barnes and Brown, 2011). Pathogen control technologies such as UV system models have been emphasized to remove disease agents from culture systems due to inadequate vaccines and antibiotics (Patterson et al., 1999; Piedrahita, 2003; Sharrer and Summerfelt, 2007).

UV sterilization units are commonly installed for sea and freshwater disinfection, and are also used for control in aquaculture systems (Rosenthal, 1981). Its widespread use is largely due to factors such as high disinfection efficiency, minimal presence of disinfection by products, ease of use and low cost (Lazarova et al., 1999; Gómez et al., 2007; Barnes and Brown, 2011). UV irradiation inactivates microorganisms by damaging their DNA and RNA, which prevents them from replicating and causing infection. The ability of UV to inactive microorganisms is dependent on the applied UV dose, given as $\mathrm{mWscm}^{-2}$ (microwatt second per centimetre squared), which is the product of UV light intensity, residence time and UV transmittance through water. In commercial applications, the normal UV dose is $30-35 \mathrm{mWscm}^{-2}$, which is sufficient for disinfection of the most common bacteria in aquaculture applications (Rodrigues and Gregg, 1993; Liltved et al., 1995; Wedemeyer, 1996; Summerfelt, 2003; Timmons and Ebeling, 2010; Barnes and Brown, 2011; Lekang, 2013).

For water treatment with UV rays, the water must be contact in suitable conditions and in sufficient time. Optimum disinfection efficiency from a UV lamp can be possible with a UV irradiation system which is designed to suitable the lamp and/or system. Therefore, UV filtration units can be made at various types and capacities (Timmons and Ebeling, 2010; Lekang, 2013). So, the present study was planned to determine whether the designing of UV irradiation prototypes could effect 
disinfection performance and operating costs for aquaculture purposes.

\section{MATERIALS AND METHODS}

In the study, pressureized U-PVC pipes (PN 6) and fittings (PN 6), 65 watts of low-pressure high-intensity UV lamps (GPH $846 \mathrm{~T} 5 / \mathrm{L} \mathrm{HO} / 4 \mathrm{PIN})$ and quartz sleeves $(20 \times 23 \times 900 \mathrm{~mm})$ were used for construction of the UV filter prototypes $(\mathrm{H}$ and $\mathrm{U})$. $A$ commercial UV unit (I) (La Purifica ${ }^{\circledR}$, UV output power per lamp: $65 \mathrm{~W}$, and capacity: $30 \mathrm{~m}^{3} \mathrm{~h}^{-1}$ ) were used for control (Fig. 1). The UV filter prototypes were designing according to the using flow rate of the commercial UV filter and also limited place in the system. Control panels were used for each ultraviolet filter systems. Also, open flow-through seawater system (flow rate, $\left.30 \mathrm{~m}^{3} \mathrm{~h}^{-1}\right)$ were used during the experiments. Sea water was filtered by a sand filter with $20-50 \mu \mathrm{m}$ filtration capability before passed through the UV filters.

The UV density can be defined as the amount of radiation per unit surface area and the following equation can be used to find the radiation dose at distance $L$ from the UV radiation source:

$$
D=\left(\frac{P}{S}\right) \times T_{0}^{L} \times t \quad \text { (Gebauer et al., 1992) }
$$

where $\mathrm{D}$, radiation dose $\left(\mathrm{mWscm}{ }^{-2}\right) ; \mathrm{P}$, radiation effect $(\mathrm{W}) ; \mathrm{S}$, area of radiated surface $\left(\mathrm{cm}^{2}\right) ; T_{0}$, transmission through $1 \mathrm{~cm}$ of water (\%; as $95 \%$ for the present study); L, thickness of the water layer that is radiated $(\mathrm{cm})$; $t$, necessary time for radiation (s).

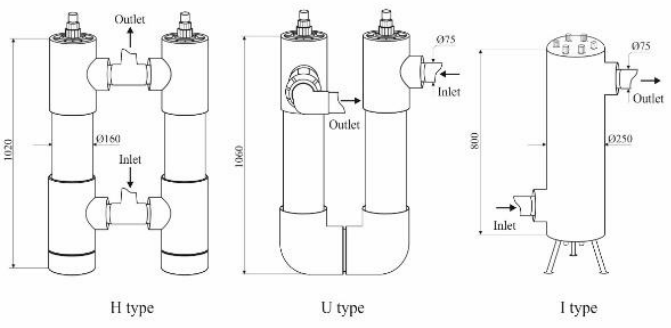

Figure 1. The UV units (the prototyeps, $\mathrm{H}$ and $\mathrm{U}$; commercial, I)

Total heterotrophic bacteria counts were measured in water samples collected immediately before and immediately after the UV units in four replicates at $15^{\circ} \mathrm{C}$ and $25^{\circ} \mathrm{C}$ of seawater temperatures. The inlet and outlet samples were collected from $5.0 \mathrm{~cm}$ diameter sterilized sample valves that were located within $5 \mathrm{~m}$ of the inlet and outlet of the UV chambers. Water samples were firstly collected from the outlet of the UV units by opening the sample valve and allowing as $1.3 \mathrm{Imin}^{-1}$ of water flow to the tank. Water flowing out of the sample point was collected in autoclave sterilized $100 \mathrm{ml}$ colored glass bottles without touching the sample point and after have been flowed for at least three minutes. The sample valve at the outlet of the UV units was then closed and the same water sampling procedure was again initiated by opening the sampling valve at the inlet of the UV chambers.

"Standart Plate Count Technique" was used from culture counting techniques for "Total Heterotrophic Bacteria" counting. Counts of live heterotrophic bacteria were made with TSA agar (Tryptic strain agarTryptone Soya Agar -caseinpeptone-soymeal-peptone) (Oxoid CM0131) containing 3/4 seawater and 1/4 fresh water, which was prepared in the laboratory. Samples were cultured surface of growth medium and the results were reported as number of bacteria per colony forming unit (CFU). Counts of viable heterotrophic bacteria (CFU) were made in modified tryptone soya agar after 3 days of culture at $25^{\circ} \mathrm{C}$. Dilutions were prepared in modified sterile TSB (Tryptone Soya Broth) (Oxoid CM0129) solution. Plates were set up in duplicate for each plated dilution. At the end of this period, colonies of bacteria growing in petri dishes were determined as Colony Forming Units (CFU) per $1 \mathrm{ml}$ sample, and the results were evaluated as zero on plates without any bacterial colon (Leonard etal., 2000; Sharrer and Summerfelt, 2007). Standard deviations of dilution repeats in each UV unit design of water samples were determined separately and the bacterial retention efficiency of the UV chambers was calculated using the following equation (Sharrer et al., 2005):

bacteria removal $(\%)=\left[\left(\right.\right.$ countinlet - count $\left._{\text {outlet }}\right) /$ countinlet] $\times 100$

Then, the LOG10 reduction of bacteria was calculated using the following equation:

\section{LOG10 reduction $=-\log _{10}[1-($ percent removal $/ 100)]$}

As an example, a 1.0 LOG10 bacteria reduction would correspond to $90 \%$ removal efficiency and a 2.0 LOG10 bacteria reduction would correspond to $99 \%$ removal efficiency.

The results were tested by using chi-square test $\left(X^{2}\right.$; $P=0.05)$ by SPSS 15.0 package software. The values in the text were given as "mean \pm standard deviation".

In addition, operating costs of the UV filters were calculated according to their electricity consumptions and renewal costs.

\section{RESULTS}

The irradiaton intensities of the chambers were calculated as $56.3 \mathrm{mWscm}^{-2}$ for $\mathrm{H}$ type, $63 \mathrm{mWscm}^{-2}$ for $\mathrm{U}$ type, and 88.7 $\mathrm{mWscm}^{-2}$ for I.

The filtration efficiencies of UV filters, operated individually for each water sample, were shown in Table 1 and Table 2 according to the water temperatures. Given the total heterotrophic bacterial load reduction efficiencies of the filters, although significant differences were not found statistically, the best results were obtained from the $U$ type UV unit at both temperatures $\left(15^{\circ} \mathrm{C}\right.$ and $\left.25^{\circ} \mathrm{C}\right)(\mathrm{P}>0.05)$. 
Table 1. Counts of total heterotrophic bacteria at $15^{\circ} \mathrm{C}$

\begin{tabular}{|c|c|c|c|c|}
\hline $15^{\circ} \mathrm{C}$ & Inlet water & $\begin{array}{l}\mathrm{H} \\
\left(56.3 \mathrm{~m} \mathrm{Wscm}^{-2}\right)\end{array}$ & $\begin{array}{l}\text { U } \\
\left(63 \mathrm{~m} \mathrm{Wscm}^{-2}\right)\end{array}$ & $\begin{array}{l}\text { I } \\
\left(88.7 \mathrm{~m} \mathrm{Wscm}^{-2}\right)\end{array}$ \\
\hline${ }^{*} \mathrm{THB}$ & $177.5 \pm 17.1$ & $14.0 \pm 7.1$ & $7.25 \pm 2.22$ & $14.5 \pm 6.4$ \\
\hline THB filtration (\%) & - & $92.11 \pm 3.78$ & $95.83 \pm 1.52$ & $92.0 \pm 3.0$ \\
\hline THB filtration $\left(\log _{10}\right)$ & - & $1.09 \pm 0.25$ & $0.85 \pm 0.13$ & $1.13 \pm 0.2$ \\
\hline
\end{tabular}

${ }^{*}$ THB: Total heterotrophic bacteria (cfu ml-1)

Table 2. Counts of total heterotrophic bacteria at $25^{\circ} \mathrm{C}$

\begin{tabular}{|c|c|c|c|c|}
\hline $25^{\circ} \mathrm{C}$ & Inlet water & $\begin{array}{l}\mathrm{H} \\
\left(56.3 \mathrm{~m} \mathrm{Wscm}^{-2}\right)\end{array}$ & $\begin{array}{l}\mathrm{U} \\
\left(63 \mathrm{~m} \mathrm{Wscm}^{-2}\right)\end{array}$ & $\begin{array}{l}\text { I } \\
\left(88.7 \mathrm{~m} \mathrm{Wscm}^{-2}\right)\end{array}$ \\
\hline${ }^{*} \mathrm{THB}$ & $1162.5 \pm 89.58$ & $167.5 \pm 51.88$ & $105 \pm 12.91$ & $137.5 \pm 35.94$ \\
\hline THB filtration (\%) & - & $85.68 \pm 3.8$ & $90.95 \pm 1.0$ & $88.21 \pm 2.7$ \\
\hline THB filtration $\left(\log _{10}\right)$ & - & $2.21 \pm 0.13$ & $2.02 \pm 0.05$ & $2.13 \pm 0.1$ \\
\hline
\end{tabular}

${ }^{*}$ THB: Total heterotrophic bacteria (cfu ml-1)

The power consumption, renewal and repair costs, and operating costs of the $\mathrm{H}$ and $\mathrm{U}$ types UV filters were estimated as $1 / 3$ of the commercial one.

\section{DISCUSSION}

Unfortunately, limited studies have been conducted on UV irradiation unit performance, and they focused on especially species-specific and/or system-specific (Lazarova et al., 1999; Gómez et al., 2007; Sharrer et al., 2005; Sharrer and Summerfelt, 2007; Timmons and Ebelling, 2010). Therefore, the present findings have been tried to be discussing within themselves and with the relevant literature as much as possible, although the obtained results could not have been discussed as desired.

According to the present results, the UV irradiation prototypes ( $\mathrm{H}$ and $\mathrm{U})$ can be replaced with the commercial one. More, considering the efficiency of reduction the total heterotrophic bacterial load of the UV filters, although significant differences were not found statistically, the best results were obtained from $U$ type UV chamber at both temperatures $\left(15^{\circ} \mathrm{C}\right.$ and $\left.25^{\circ} \mathrm{C}\right)(\mathrm{P}>0.05)$. This result is thought to be due to the effect of UV irradiation unit design. Namely, all water entering from one point of the UV unit, has better filtration due to exposed to the rays of both ultraviolet lamps.

The UV doses calculated for the both prototypes and commercial UV filters were higher than those commonly used in aquaculture (Rodrigues and Gregg, 1993; Liltved et al., 1995; Timmons and Ebeling, 2010; Lekang, 2013) and lower than log 3 values (log 1.97-2.34). It is thought that this is related to the prototypes, which were designing to base on the technical specifications of the commercial UV chamber, and the water flow rate.

\section{REFERENCES}

Barnes, M.E. \& Brown, M.L. (2011). A review of Flavobacterium psychrophilum biology, clinical signs, and bacterial cold water disease prevention and
There are many factors that affecting the efficient operation of UV lamps. These are; UV lamp life efficiency, the cleaning of the lamp surface, the distance of the organisms in contact with the lamps, the type of organisms, the UV application period and the water clarity. UV lamps must be changed at least once in a year (Timmons and Ebeling, 2010). Normally it is recommended to change the UV lamp, when the UV effect detected by the UV sensor to under $60 \%$ (Rodrigues and Gregg, 1993). In this study, six 65 watt UV lamps and six quartz sleeves were required for the commercial UV filter, while two 65 watt UV lamps and two quartz sleeves for the prototypes were sufficient. Thus, it is only possible to save about $60 \%$ per year in renewal and operating costs by changing the design of the UV filters.

In conclusion, the obtained findings demonstrated that by these designs same amount of water could be disinfecting for both much cheaper and more efficiently in terms of aquaculture. Furthermore, the current research showed that more than $60 \%$ can be saved in operating and renovation costs by changing the design of UV irradiation unit, when the UV dose would have been equielly calculated as $30-35 \mathrm{mWscm}^{-2}$. However, it should be noted that the UV filters designed for this study were prototypes and must be developed strictly. Therefore, further studies on design/cost performance of UV irradiation units for aquaculture purposes are needed.

\section{ACKNOWLEDGEMENTS}

This study was funded by Ege University, Scientific Research Project, 13-SUF-015. The authors extend their gratitude to Assoc. Prof. Dr. Ozan DUZBASTILAR for drawing technical illustrations. Also, the authors gratefully acknowledge to Selim SEREZLI, MSc. and Oğuzhan TAKICAK, MSc. for their invaluable assistance during the study. treatment. The Open Fish Science Journal, 4, 40-48. DOI: 10.2174/1874401X01104010040 
Gebauer, R., Eggen, G., Hansen, E. \& Eikebrokk, B. (1992) Oppdrettsteknologi: vannkvalitet og vannbehandling i lukkede oppdrettsanlegg. Tapir Forlag [in Norwegian].

Gómez, M., Plaza, F., Garralón, G., Pérez, J. \& Gómez, M.A. (2007). A comparative study of tertiary wastewater treatment by physico-chemicalUV process and macrofiltration-ultrafiltration technologies. Desalination, 202, 369-376. DOI: 10.1016/j.desal.2005.12.076

Lazarova, V., Davoye, P., Janex, M.L., Blatchley, E.R. \& Pommepuy, M. (1999). Advanced wastewater disinfection technologies: state of the art and perspectives. Water Science Technology, 40(4-5), 203-213. DOI: 10.1016/S0273-1223(99)00502-8

Leonard N., Blancheton J.P. \& Guiraud J.P. (2000). Populations of heterotrophic bacteria in an experimental recirculating aquaculture system. Aquacultural Engineering, 22(1-2), 109-120. DOI: 10.1016/s0144-8609(00)00035-2

Lekang, O. I. (2013). Aquaculture Engineering (Second Edition). John Wiley \& Sons, Ltd., UK

Liltved, H., Hektoen, H. \& Efrainsen, H. (1995). Inactivation of bacterial and viral fish pathogens by ozonation or UV radiation in water of different salinity. Aquacultural Engineering, 14(2), 107-122. DOI: 10.1016/0144-8609(94)P4430-J

Patterson, R.N., Watts, K.C. \& Timmons, M.B. (1999). The power law in particle size analysis for aquacultural facilities. Aquacultural Engineering, 19(4), 259-273. DOI: 10.1016/S0144-8609(98)00054-5

Piedrahita, P.H. (2003). Reducing the potential environmental impact of tank aquaculture effluents through intensification and recirculation. Aquaculture, 226(1-4), 35-44. DOI: 10.1016/S0044-8486(03)00465-4
Rodrigues, J. \& Gregg, T.R. (1993). Consideration for the use of ultraviolet in fish culture. In: Techniques for modern aquaculture (ed. Wang, J.K.), Proceedings Aquacultural Engineering Conference, Spokane, Washington. ASAE Publication 02-93, American Society of Agricultural Engineers.

Rosenthal, H. (1981). Ozonation and sterilization. In Proceedings from the World Symposium on Aquaculture in Heated Effluents and Recirculation System Vol.I (Edited by Tiens K.), pp. 21 9-274. Hccnemann, Berlin, Germany.

Sharrer, M.J., Summerfelt, S.T., Bullock, G.L., Gleason, L.E. \& Tauber, J. (2005). Inactivation ofbacteria using ultraviolet irradiation in recirculating salmonid culture system. Aquaculture Engineering, 33, 35-149. DOI: 10.1016/j.aquaeng.2004.12.001

Sharrer, M.J. \& Summerfelt, S.T. (2007). Ozonation followed by ultraviolet irradiation provides effective bacteria inactivation in a freshwater recirculating system. Aquacultural Engineering, 37(2), 180-191 DOI: 10.1016/j.aquaeng.2007.05.001

Summerfelt, S.T. (2003). Ozonation and UV irradiation - an introduction and examples of current applications. Aquacultural Engineering, 28(1-2), 2136. DOI: 10.1016/S0144-8609(02)00069-9

Timmons, M. B. \& Ebeling, J. M. (2010). Recirculating Aquaculture (Second Edition). NRAC Publication No, 401-2010, Cayuga Aqua Ventures, New York 14850, USA

Wedemeyer, G.A. (1996). Managing pathogen exposure. In: Physiology of Fish in Intensive Culture Systems. Chapman and Hall, New York, USA 